the explosive sounds. (How the author expects writers to maintain this distinction when writing or printing in capitals is again not made clear.)

We seem to be entering now a period of imposed alphabets by the metropolitan powers, each power being influenced by its own orthographic usage of the Latin alphabet. Thus in East Africa the Swahili alphabet (based on the principle 'vowels as in Italian, consonants as in English') is the vehicle for transcribing non-Bantu languages such as Luo and Nandi, and attempts to introduce 'Africa' conventions that conflict with this usage have been strongly resisted except in the Sudan and Uganda; in Kenya the Standing Committee on Geographical Names prescribes Swahili spelling for all vernacular place-names, while in the Belgian Congo and Portuguese Guinea different codes are officially recognized for this purpose-though in the Congo the 'Africa' system plays an increasingly important part in vernacular literature; now M. Houis enters the arena with his own French-biased system. (Thus, to take an extreme case, the sound for which the 'Africa' alphabet prescribes ' $c$ ' is to be written ' $c$ ' in Uganda, ' $c h$ ' in Kenya, 'tsh' in Belgian Congo, ' $t x$ ' in Portuguese Guinea, and presumably 'tch' in French Africa. We await with interest the Spanish and Italian contributions to the medley.) This divergence, be it noted, concerns the ordinary letters of the Latin alphabet; even in this field (quite apart from the question of ' new letters') the co-ordinating work of the International African Institute is being undone, and we find ourselves back to the confusions of I926. Meanwhile the 'Africa' alphabet, the only truly international one, still functions as a guide to missionaries and research workers all over Africa, and it is surely not too late now for this fact to be taken into account at official levels.

A. N. T.

\title{
Second Annual Congress of the Historical Society of Nigeria
}

THE second annual congress of the Historical Society of Nigeria was held at Ibadan on 17 and 18 December 1957. The society, which was founded three years ago, aims to promote interest in and to study the history of Nigeria, to encourage research by members and to improve the standards of history teaching in Nigeria. Membership now exceeds 350 and it is hoped that the target of 500 will soon be reached. Groups of historians have been meeting regularly in Zaria and Enugu during the past year.

Professor K. O. Dike presided over most of the sessions and the congress was opened with an illustrated lecture on 'Swords and Armour of Muslim Nigeria ' by Mr. A. D. H. Bivar, Government Archaeologist working in the Museum at Jos. Other papers were: 'Written descriptions of the Niger's eastern delta by travellers of the sixteenth and seventeenth centuries', by Dr. A. F. C. Ryder; 'Contribution to the study of the origins of the Fulani jihad in Northern Nigeria ', by Captain M. Hiskett of the Kano School for Arabic Studies; 'The origins of the craft guilds of Bida', by Mr. H. O. H. Vernon-Jackson, Provincial Education Officer, Bornu; 'The establishment of British administration in the Urhobo country', by Mr. A. Salubi, Assistant Commissioner of Labour, Ibadan; 'Early British expansion on the Benue, 1830-1900', by Mr. A. H. M. Kirk-Greene of the School of Administration, Zaria; ' The age of Ewuare: a history of Benin from the mid-fifteenth to the mid-sixteenth century', by Mr. O. I. Afe of the Western Region Ministry of Finance. The congress closed with papers and reports on the schemes of historical research now in hand. These were given by Mr. P. Morton-Williams of the Yoruba Historical Research Scheme, who also spoke on 'Research into Yoruba traditions at Oyo'. Dr. Ryder of the History Department of the University College also added a note on the progress of the Benin Research Scheme; he is now preparing to study the European archives. During the congress the College's Deputy Librarian, Mr. J. Packman, formerly Librarian to the Royal Empire Society, arranged an exhibition of historical documents in the well stocked room of Africana. 
The papers given at the congress will be published in the society's journal. The society also publishes a quarterly Bulletin, which contains a bibliography of current publications on the history of Nigeria and its neighbours.

\section{New Discoveries at Ife}

EARLY this year an important archaeological discovery was made at Ita Yemoo on the outskirts of Ife by a workman engaged in clearing a low mound to level a site for building. The bronzes were deeply patinated and appear to have lain undisturbed for a considerable period. They were taken to the Ife Museum for temporary exhibition before receiving laboratory treatment, and have now been exhibited at the British Museum and the Manchester University Museum. The finds include the standing figure of an Oni in full regalia, about nineteen inches high; a group of two figures, one of them probably a woman, arm-inarm and dressed in royal attire; two ceremonial staffs, probably used by the Ogboni society; two egg-shaped objects, each with two heads; and a small heavy brass object in the form of a drinking-cup, ornamented with a richly dressed royal female personage reclining on a stool. The site of the discovery, which has been purchased for Nigeria's Antiquities Department, has been excavated by Mr. Frank Willett of the Manchester Museum, and application has been made for the surrounding area to be declared a national monument until the full extent of the site is known.

\section{Discovery of Rock Paintings in Bauchi}

A NUMBER of cave paintings have been discovered recently in the Northern Region of Nigeria by the District Officer of Bauchi Division, Mr. H. Sassoon, at Geji, some twenty miles from Bauchi town. The paintings-about fifteen in all-are in a large open cave, five miles from the nearest track suitable for vehicles. There are two groups on the main wall of the cave, which is sheltered by trees; the deep red pigment has therefore been preserved, though some of it has been scraped away for ' magical ' purposes connected with fertility rites. The paintings are of large straight-horned African antelopes, monkeys, cows, and what appear to be human figures. A further outline is probably a horse, and if this is verified it may help to date the paintings at 800 to 850 years old. The first such find was at BirninKudu, Kano Province, in 1953, and consisted of cattle and some geometric designs.

\section{Margaret Wrong Memorial Fund: Award for 1957}

THE Margaret Wrong Prize for 1957 has been awarded to the Rev. J. J. R. Jolobe, for outstanding services to literature in South Africa. Mr. Jolobe has produced a great volume of writing in Xhosa and has done valuable work on the Xhosa Language Committee at Lovedale. 